\title{
PENGARUH PERAWATAN PAYUDARA (BREAST CARE) TERHADAP VOLUME ASI PADA IBU POST PARTUM (NIFAS) DI RSUD DELI SERDANG SUMUT TAHUN 2012
}

\author{
Sri Wulan', Rahmad Gurusinga ${ }^{2}$ \\ email: wulan194@gmail.com \\ STIKes Medistra Lubuk Pakam, Jln Jenderal Sudirman No.38 Lubuk Pakam \\ Kabupaten Deli serdang, Sumut Telp (061) 7952262
}

\begin{abstract}
ABSTRAK
Masa nifas merupakan masa pulih kembali mulai dari persalinan selesai sampai alat-alat kandungan kembali seperti pra-hamil. Diperkirakan 60\% kematian ibu akibat kehamilan terjadi sertelah persalinan dan $50 \%$ kematian masa nifas terjadi dalam 24 jam pertama. Dari antara 60\% tersebut disebabkan oleh kurangnya pearawatan masa nifas, termasuk perawatan payudara. Tujuan penelitian ini untuk mengetahui pengaruh perawatan payudara (breast care) terhadap peningkatan volume ASI pada ibu post partum (Nifas) di Ruangan Melati RSUD Deli Serdang, sumut. Jenis penelitian ini adalah pre eksperimental (pra experiment) dengan model rancangan one group pretest posttest. Data diambil dengan menggunakan lembar observasi yang selanjutnya dianalisa. Populasi dalam penelitan ini adalah seluruh ibu post partum yang ada di ruangan melati RSUD Deli Serdang sebanyak 18 orang. Berdasarkan hasil uji paired t test menunjukan bahwa rerata sebelum breast care $=4,50$, Rerata sesudah breast care $=6,44$ dengan nilai $P$ value 0,021 yang berarti $\leq$ dari 0,05 . Hal tersebut menunjukkan bahwa terdapat pengaruh yang positif antara sebelum dan sesudah breast care. Kesimpulanya ada pengaruh yang signifikan terhadap volume ASI pada ibu post partum sebelum dan sesudah diberikan perawatan payuda (breast care). Disarankan kepada para tenaga kesehatan agar dapat melakukan perawatan payudara untuk meningkatkan produksi ASI .
\end{abstract}

Kata Kunci : Perawatan Payudara (breast care), Volume ASI

\section{Pendahuluan}

Masa nifas (puerpurium) adalah waktu yang dimulai setelah placenta lahir dan berakhir kira-kira 6 minggu. Akan tetapi seluruh alat kandungan kembali seperti semula (sebelum hamil) dalam waktu kurang lebih 3 bulan. Pasca melahirkan (masa nifas) merupakan masa atau keadaan selama enam minggu atau 40 hari. Pada masa ini, ibu mengalami perubahan fisik dan alat-alat reproduksi yang kembali ke keadaan sebelum hamil. ${ }^{1}$

Masa nifas atau puerperium merupakan masa pulih kembali mulai dari persalinan selesai sampai alat-alat kandungan kembali seperti prahamil. Diperkirakan 60\% kematian ibu akibat kehamilan terjadi sertelah persalinan dan 50\% kematian masa nifas terjadi dalam 24 jam pertama. Dari antara 60\% tersebut disebabkan oleh kurangnya pearawatan masa nifas, termasuk perawatan payudara. ${ }^{2}$

Salah satu masalah menyusui pada masa nifas yaitu bendungan air susu (engorgement of the breast). Bendungan air susu terjadi yaitu karena penyempitan duktus laktiferi atau oleh kelenjar-kelenjar yang tidak dikosongkan dengan sempurna, atau karena kelainan pada putting susu. Keluhan yang dirasakan antara lain payudara bengkak, keras, nyeri.
Penanganan sebaiknya dimulai selama hamil dengan perawatan payudara untuk mencegah terjadinya kelainan-kelainan dan tetap berlanjut sampai masa nifas. ${ }^{3}$

Organisasi kesehatan dunia (2007) memperkirakan lebih dari 1,4 juta orang tidak mengerti tentang perawatan payudara. The American Society memperkirakan 241.240 wanita Amerika Serikat mengalami masalah karena payudara yang kurang bersih. Sedangkan di Kanada jumlah wanita mengalami masalah dengan kebersihan payudara adalah 24.600 orang dan di Australia sebanyak 14.791 orang. Di Indonesia diperkirakan berjumlah 876.665 orang dan di Sumatera Utara berkisar 40-60\% wanita yang tidak mengerti sama sekali mengenai perawatan payudara. ${ }^{4}$

Salah satu masalah yang terjadi karena kurangnya perawatan payudara adalah penurunan produksi ASI. Produksi dan pengeluaran ASI dipengaruhi oleh dua hormon, yaitu prolaktin dan oksitosin. Prolaktin mempengaruhi jumlah produksi ASI, sedangkan oksitosin mempengaruhi proses pengeluaran ASI. Perawatan payudara sangat penting salah satunya menjaga kebersihan payudara, terutama kebersihan putting susu agar terhindar dari infeksi, melunakkan serta memperbaiki bentuk putting susu sehingga bayi dapat menyusu 
dengan baik, merangsang kelenjar-kelenjar dan hormone prolaktin dan oksitosin untuk meningkatkan produksi ASI lancar serta mengetahui secara dini kelainan putting susu dan melakukan usaha-usaha untuk mengatasinya. ${ }^{5}$

Berdasarkan hasil survei lapangan ditemukan jumlah ibu yang melahirkan selama 3 bulan terakhir sebanyak 43 orang. Awal bulan 5 jumlah ibu yang melahirkan yang rawat inap di ruangan melati 9 orang. Dari keseluruhan ibu tersebut tidak pernah melakukan perawatan payudara dengan baik, sehingga banyak ketidak nyamanan yang terjadi. ${ }^{6}$

Penelitian ini bertujuan untuk mengetahui pengaruh perawatan payudara (breast care) terhadap peningkatan volume ASI pada ibu post partum (Nifas) di Ruangan Melati RSUD Deli Serdang Tahun Lubuk Pakam 2012.

\section{Metode Penelitian}

Jenis penelitian ini adalah pra eksperimental, desain penelitian one group pretest posttest. ${ }^{7}$ penelitian dilaksanakan di Ruangan Melati RSUD Deli Serdang, Sumut. mulai bulan Maret-Juli 2012. Sampel dalam penelitan ini adalah seluruh ibu post partum yang ada di ruangan melati RSUD Deli Serdang sebanyak 18 orang. Teknik pengambilan sampel dengan tehnik purposive sampling yang ditentukan sesuai dengan kriteria inklusi. Pengambilan data dengan menggunakan lembar observasi yang berisi tentang data demografi dan tabung pengukur volume ASI. Analisa data dengan menggunakan Uji statistik Paired Sample t-test dengan alpha 0,05 . $^{8}$

\section{Hasil dan Pembahasan}

\section{a. Hasil Univariat}

Tabel 1. Distribusi Frekuensi Kategori

Volume ASI Pada Ibu Post Partum Sebelum Perawatan Payudara

\begin{tabular}{clll}
\hline No & Volume ASI & $\mathbf{N}$ & \multicolumn{1}{c}{$\%$} \\
\cline { 2 - 4 } 1. & Meningkat & 1 & 5,6 \\
\cline { 2 - 4 } 2. & Tidak Meningkat & 17 & 94,4 \\
\cline { 2 - 4 } & Total & $\mathbf{1 8}$ & $\mathbf{1 0 0 \%}$ \\
\hline
\end{tabular}

Dari tabel 1 di atas dapat dilihat bahwa responden dengan kategori volume ASI meningkat sebanyak 1 orang $(5,6 \%)$ dan responden dengan kategori volume ASI tidak meningkat sebanyak 17 orang $(94,4 \%)$.

Dari hasil diketahui responden yang memiliki peningkatan ASI hanya 1 orang. Hal ini dikarenakan ibu yang tidak mau menyusui dengan berbagai alasan. Misalnya takut gemuk, sibuk, payudara kendor dan sebagainya. Di lain pihak, ada juga ibu yang ingin menyusui bayinya tetapi mengalami kendala yaitu tidak keluarnya ASI atau tidak lancar. Selain itu juga banyak hal yang dapat mempengaruhi produksi ASI.

Salah satu masalah yang terjadi karena kurangnya perawatan payudara adalah penurunan produksi ASI. Produksi dan pengeluaran ASI dipengaruhi oleh dua hormon, yaitu prolaktin dan oksitosin. Prolaktin mempengaruhi jumlah produksi ASI, sedangkan oksitosin mempengaruhi proses pengeluaran ASI. Perawatan payudara sangat penting salah satunya menjaga kebersihan payudara, terutama kebersihan putting susu agar terhindar dari infeksi, melunakkan serta memperbaiki bentuk putting susu sehingga bayi dapat menyusu dengan baik, merangsang kelenjar-kelenjar dan hormone prolaktin dan oksitosin untuk meningkatkan produksi ASI lancar serta mengetahui secara dini kelainan putting susu dan melakukan usaha-usaha untuk mengatasinya. ${ }^{9}$

Tabel 2. Distribusi Frekuensi Kategori Volume ASI Pada Ibu Post Partum Sesudah Perawatan Payudara

\begin{tabular}{clll}
\hline No & Volume ASI & $\mathbf{N}$ & $\mathbf{\%}$ \\
\cline { 2 - 4 } 1. & Meningkat & 16 & 88,9 \\
\cline { 2 - 4 } 2. & Tidak Meningkat & 2 & 11,1 \\
\cline { 2 - 4 } & Total & $\mathbf{1 8}$ & $\mathbf{1 0 0 \%}$ \\
\hline
\end{tabular}

Dari tabel 2 di atas dapat dilihat bahwa responden yang mengalami peningkatan volume ASI sebanyak 16 orang $(88,9 \%)$ dan responden yang tidak mengalami peningkatan volume ASI sebanyak 2 orang $(11,1 \%)$.

Perawatan payudara setelah melahirkan bertujuan agar payudara senantiasa bersih dan mudah di hisap oleh bayi. Banyak ibu yang mengeluh bayinya tidak mau menyusu, bisa jadi ini di sebabkan oleh faktor teknis seperti puting susu yang masuk atau posisi yang salah. Selain faktor teknis ini tentunya Air Susu Ibu juga di pengaruhi oleh asupan nutrisi dan kondisi psikologis ibu ${ }^{9}$ 
Pada masa nifas perawatan payudara merupakan suatu tindakan yang sangat penting untuk merawat payudara terutama untuk memperlancar pengeluaran ASI. Perawatan payudara sangat penting dilakukan selama hamil sampai masa menyusui. Hal ini karena payudara merupakan satu-satunya penghasil ASI yang merupakan makanan pokok bayi yang baru lahir sehingga harus dilakukan sedini mungkin. Dimana tujuan perawatan payudara setelah melahirkan, salah satunya untuk meningkatkan produksi ASI dengan merangsang kelenjar-kelenjar air susu melalui pemijatan. $^{10}$

Tabel 3 Perbedaan Rerata antara

Sebelum Dan Sesudah

Perawatan Payudara

\begin{tabular}{lcc}
\cline { 1 - 1 } Perawatan payudara & Rerata & P value \\
\cline { 1 - 2 } Sebelum & 4,50 & 0,021 \\
\cline { 1 - 2 } Sesudah & 6,44 & \\
\hline
\end{tabular}

Berdasarkan hasil uji statistik dengan menggunakan uji paired $t$ test menunjukan bahwa rerata volume ASI sebelum perawatan payudara yaitu 4,50 , rerata volume ASI sesudah perawatan payudara yaitu 6,44 dengan nialai $P$ value 0,021 yang berati $<0,05$. Hal tersebut menunjukkan bahwa terdapat pengaruh yang positif antara sebelum dan sesudah perawatan payudara.

Hasil Penelitian ini sejalan dengan penelitaian yang dilakukan oleh Amalia 2006 menunjukkan bahwa perawatan payudara membawa dampak positif dalam meningkatkan volume ASI, $75 \%$ ibu yang mendapat perawatan payudara mendapat peningkatan volume ASI dan 25\% ibu yang tidak mendapat perawatan payudara yang dikarenakan oleh adanya fakktor lainnya. ${ }^{9}$

Menrut teori Tujuan Perawatan Payudara yaitu meningkatkan produksi ASI dengan merangsang kelenjar-kelenjar air susu melalui pemijatan, mencegah bendungan ASI/ pembengkakan payudara, melenturkan dan menguatkan putting, mengetahui secara dini kelainan puting susu dan melakukan usaha untuk mengatasi. ${ }^{11}$

Pada penelitian ini Perawatan payudara dilakukan 3 kali selama satu minggu yaitu dengan cara merangsang atau memijat payudara ibu, dan membersihkan putting susu ibu serta mengompres payudara ibu dengan air hangat dan air dingin secara bergantian selama 2 menit, yang dapat mempengaruhi hipopises untuk mengeluarkan hormone progesterone dan estrogen sehingga mengasilkan hormone oksitosin. Dari hasil penelitian Hal tersebut dapat meningkatkan produksi ASI sehingga kebutuhan bayi akan ASI dapat tercukupi dengan baik. dan bayi tanpak tenang serta tidak rewel.

Dari hasil penelitian menunjukkan bahwa ada 2 responden yang ASInya tidak meningkat, hal ini disebabkan karena terdapat lecet pada putting susu ibu sehingga tidak dapat diberikan perawatan payudara secara maksinmal karena ibu merasakan sakit pada area putting ibu. Meskipun demikian perawatan payudara (breast care) mempunyai pengaruh yang positif terhadap peningkatan jumlah ASI Oleh karena itu perawatan payudara perlu diterapkan oleh ibu post partum.

\section{Kesimpulan}

Berdasarkan hasil yang diperoleh maka dapat disimpulkan bahwa Sebelum dilakukan perawatan payudara dari 18 responden terdapat $1(5,6 \%)$ responden dengan kategori volume ASI meningkat dan 17 orang $(94,4 \%)$ responden dengan kategori volume ASI tidak meningkat, sedangkan Sesudah dilakukan perawatan payudara terdapat $16(88,9 \%)$ responden yang mengalami peningkatan volume ASI dan $2(11,1 \%)$ responden yang tidak mengalami peningkatan volume ASI. Dan dari hasil uji paired t test diperoleh nialai $p$ value 0,021 yang berarti signifikansi $\leq 0.05$. Maka Hipotesa dalam penelitian ini diterima yang berarti ada pengaruh yang signifikan terhadap volume ASI pada ibu post partum sebelum dan sesudah diberikan perawatan payudara.

Agar ibu post partum dapat secara mandiri melaksanakan perawatan payudara untuk meningkatkan produksi ASI. Maka disarankan kepada para tenaga kesehatan khususnya bidan agar dapat menerapakan dan mengajarkan cara-cara perawatan payudara sejak dini (hamil).

\section{Daftar Pustaka}

[1] Saryono, 2009. Panduan Kesehatan Balita: Petunjuk Lengkap Untuk Orang Tua dari Masa Kehamilan Sampai Usia 
Anak 5 Tahun. http://www.scribd.com di akses tanggal 3 Januari 2012.

[2] Ambarwati, 2010. Asuhan Kebidanan Nifas. Nuha Medika, Yogyakarta.

[3] Hesti, 2009. Perawatan Masa Nifas. ALFABETA, Bandung.

[4] Depkes, 2008. Perawatan Payudara Pada Ibu Nifas. http//www.Depkes.go.id. Diakses tanggal 30 April 2012

[5] Roesli Utami. 2009. ASI Eksklusif. Trubus Agriwidya, Jakarta

[6] Data laporan tahunan RSUD Deli Serdang tahun 2011

[7] Riyanto A, 2011. Aplikasi Metodologi Penelitian Kesehatan. Yogyakarta : Nuha Medika.

[8] Andi. 2007. Panduan Praktis Pengolahan Data Statistik Dengan SPSS 15.0. Yogyakarta : Wahana Komputer.

[9] Amalia, 2006. Pengaruh Perawatan Payudara Terhadap Peningkatan Volume ASI. http://els.fk.umy.ac.id. Diakses tanggal 30 April 2012

[10]Pramitasari, 2009. Perawatan Payudara. http://els.fk.umy.ac.id. Diakses tanggal 30 April 2012

[11]Hadi, 2008. ibu dan bayi : http://nursingbegin.com. Diakses tanggal 5 Mei 2012 